\title{
EXTRACTING LEADING INDICATORS OF BANK FRAGILITY FROM MARKET PRICES - ESTONIA FOCUS
}

\author{
YU-FU CHEN \\ MICHAEL FUNKE \\ KADRI MÄNNASOO
}

\author{
CESIFO WORKING PAPER NO. 1647 \\ CATEgory 6: MONETARY POLICY AND INTERNATIONAL FinANCE \\ JANUARY 2006
}

\footnotetext{
An electronic version of the paper may be downloaded

- from the SSRN website: www.SSRN.com

- from the CESifo website: www.CESifo-group.de
} 


\title{
EXTRACTING LEADING INDICATORS OF BANK FRAGILITY FROM MARKET PRICES - ESTONIA FOCUS
}

\begin{abstract}
Banking reform has proved to be one of the most problematic elements of economic transition in central and Eastern Europe. Therefore the paper considers the development of the Estonian banking sector and derives individual banks' fragility scores during transition. To this end we use option-based tools and equity prices to estimate distance-to-default measures of banks' distress probabilities. Overall, the results suggest that market indicators are moderately useful for anticipating future financial distress and rating changes in transition economies. The implication for an effective supervisory framework is to use a plurality of risk scores when assessing bank vulnerability.
\end{abstract}

JEL Code: E44, E58, G21.

Keywords: banking, financial stability, bank fragility, options, Estonia.

\author{
Yu-Fu Chen \\ Department of Economic Studies \\ University of Dundee \\ Dundee DD1 4HN \\ United Kingdom \\ y.f.chen@dundee.ac.uk
}

\author{
Michael Funke \\ Department of Economics \\ Hamburg University \\ Von-Melle-Park 5 \\ 20146 Hamburg \\ Germany \\ funke@econ.uni-hamburg.de
}

\author{
Kadri Männasoo \\ Bank of Estonia \\ Estonia pst.13 \\ 15095 Tallinn \\ Estonia \\ kadri.mannasoo@epbe.ee
}

December 2005

The views expressed here are those of the authors and do not necessarily represent the official views of Eesti Pank (Bank of Estonia). 


\section{Introduction}

The number of countries experiencing banking problems has increased dramatically in recent years, with banking crises striking industrial, developing and transition economies alike. ${ }^{1}$ Furthermore, the high costs and macroeconomic disruptions caused by such banking crises have become a matter of increasing concern in the international financial community. Effective supervisory capabilities are thus vital to limit the adverse impact of these crises. Therefore, the potential for early warning models of bank vulnerability to serve as supervisory tools has been the subject of a sustained research effort in recent years.

From the existing literature on banking crises two distinct lines of thought on the phenomenon have emerged. The first views banking crises as being related to the macroeconomic business cycle and triggered by sudden changes in perceived aggregate risk. In other words, banks fail through exposure to the same common shock. The second considers banking crises to be random events, unrelated to changes in the macro economy. For example, banking crises can arise as a result of self-fulfilling expectations, as modelled by Diamond and Dybvig (1983), among others. They consider a model with two equilibria, with the "bad one" leading to a self-fulfilling, sunspots-based liquidity crisis in the banking sector. Allen and Gale (2000) and Freixas et al. (2002) model theoretically the idea of contagion arising from the spreading of bank failure through interbank exposures with potentially destabilising consequences for the economy as a whole. ${ }^{2}$

The qualitative banking and currency crisis literature, beginning with Kaminsky and Reinhart (1999), typically focuses on a combination of events in order to define what constitutes as the beginning of a banking crisis. These may include: (i) bank runs that lead to a closure, merger or takeover by the public sector of one or more financial institutions; and (ii) in the absence of runs, the closure, merger, or takeover of one or more banks or large-scale government assistance to prevent a potential bank run. ${ }^{3}$

The theoretical and qualitative literature raises the empirical question of how to measure banking fragility or banking crisis precisely. Can the complexity of a crisis be captured by a single indicator? In view of this, our objective is to develop a quantitative fragility score that could predict a banking crisis, and thereby ensuring that less time is devoted to defining the crisis itself.

This paper is composed as follows. In Section 2 the restructuring of the Estonian banking sector during transition is briefly reviewed. The distance-to-default measure is constructed in Section 3. In Section 4

\footnotetext{
${ }^{1}$ Caprio and Klingebiel (2003) provide a list of 117 systemic banking crises that have occurred in 93 countries since the late 1970s. The paper also provides information on 51 borderline and small (nonsystemic) banking crises in 45 countries. Systemic banking crises, in their definition, are those in which much or all of the banking capital in the country is exhausted. These might sound like rare events, but crises have actually occurred so frequently, in so many countries that they must be considered a global policy issue. According to Caprio and Klingebiel (2003), Estonia experienced systemic banking crises from 1992 to 1995 and a borderline banking crisis in 1998.

${ }^{2}$ A survey of theoretical models of systemic risk in banking markets is provided in De Brandt and Hartmann (2000).

${ }^{3}$ Recently, Demirgüç-Kunt and Detragiache $(1998,2001,2005)$ have combined the qualitative approach with a limited number of quantitative criteria.
} 
comprehensive case studies are conducted in order to evaluate the merits and practical usefulness of the methodology with respect to actual Estonian market data. To the best of our knowledge, we are the first to analyse the development and risk of Estonian banks with a dataset of similar quality. The timing and information content of the distance-to-default measures are critically evaluated in section 5. In Section 6 conclusions, as well as a number of policy implications, are presented.

\section{Estonian Banking Sector Development and Restructuring During Transition}

This section provides a brief overview of the unprecedented transformation of the Estonian Banking system during the transition process of ten years. Initially Estonia inherited a Soviet-style monobank system under which specialised state banks serviced specific sectors of the economy. After regaining the independence in August 1991 Estonia immediately launched the transition process and began developing a modern two-tier banking system with the central bank as its core. ${ }^{4}$ In June 1992 the Estonian national currency, the Estonian EEK, was re-introduced under a currency board system and linked to the Deutsche mark (EEK $8=$ DEM 1$)^{5}$

At the beginning of the transition period Estonia had a very liberal policy toward the licensing of new commercial banks. A large number of banks, it was thought, would provide the lending needed to support the emerging private sector. ${ }^{6}$ Little thought was given initially to the implications of this policy with respect to bank soundness and supervision. Therefore, many banks established in early years of transition lacked the necessary expertise and capital base for running a sustainable banking business.

The first systemic full-blown banking crisis to hit Estonia surfaced in 1992-1993. A large proportion of the newly founded credit institutions were not in a position to withstand the numerous stresses and strains associated with such a crisis. Among the most critical precipitators of such bank distress are: pre-monetary reform deposit withdrawal; high costs of funding; weak banking skills and mismanagement; small, but overly risky, loan portfolios; as well as poor accountability and inexperienced supervision. ${ }^{7}$ In the wake of the crisis, more than one-fourth of the banking system went bankrupt and the number of institutions fell sharply, from 42 in 1992 to 24 at the end of 1993 . Among other things, Eesti Pank suspended operations of the country's three largest banks. Tartu Commercial Bank was closed and liquidated, the Northern Estonian Bank and the Union Baltic Bank were merged

\footnotetext{
${ }^{4}$ During the transition period Estonia earned the nickname "Tiger of the Baltics". When taking-off Estonia has got two things right. The first is openess to foreign trade which is strongly associated with economic growth. The second is competition from foreign firms, whether at home or in export markets, sharply raising productivity.

${ }^{5}$ The currency board system means that Eesti Pank lending to commercial banks is only possible if there are sufficient excess reserves beyond the amount of foreign exchange reserves necessary to match the currency in circulation. This has indeed been the case in Estonia, since reserves expanded strongly since 1992.

${ }^{6}$ Contrary to several CEE countries (e.g. Poland, Czech Republic, Hungary), the newly incorporated Estonian banks did not inherit a huge stock of bad loans from the Soviet era.

${ }^{7}$ For example, in the first years of the transition from central planning to a market-based system banks continued to use the old Soviet Gosbank chart of accounts. In Estonia banks were required to use IAS accounting and reporting requirements for the first time in 1995, although the stronger banks have begun doing so already in 1993.
} 
into one entity and recapitalised. The new entity was launched under the name North Estonia Bank. The increase of the minimum capital requirements from EEK 500,000 to EEK 6 million in October 1992 triggered solvency problems and finally the liquidation of eight small credit institutions in early 1993. In March 1993, ten small rural banks were merged into a new bank Eesti Ühispank (Union Bank of Estonia). Despite this market shakeout, however, stability was not achieved. In 1994 the largest bank at the time, Eesti Sotsiaalpank (Social Bank), experienced liquidity problems and failed in May 1995.

The beginning of a new era in Estonian financial sector development was marked by the enactment of the Law on Credit Institutions in December 1994, which increased the central bank's supervision and enforcement capabilities and incorporated the standards of relevant EU laws. The subsequent years put the banks under severe pressure, forcing weaker players out of the market. The plan for improvements in prudential requirements was particularly challenging - within just four years the bank's own funds were required to reach the level of 5 million ECU, i.e. the level that most European banks adhere to. While the strongest market players were able to accumulate the required capital with new issues on stock market and reinvestments, the weakest had only two options: merge or close down. Stringent capital standards were aimed at consolidating the banking sector, thereby ensuring the improved efficiency and competitiveness. By the end of 1996 the number of banks had shrunk to a more reasonable, although not scale-efficient, level of 13 institutions. ${ }^{8}$

On 2 April 1997, as a reflection of the strain being exerted on Asian financial markets, the central bank issued a statement warning that increases in foreign funding would open banks to adverse spillover effects from international capital markets. The statement also underlined the extra risks borne by overheated real and financial markets. To counter these developments various measures aiming at longterm stability and crisis prevention were introduced. ${ }^{9}$ In practice though the timing of the restrictive actions coincided with a liquidity squeeze in the banking sector and impaired the institution's capability to withstand distress.

Financial turmoil on emerging Asian markets also led to spillover effects in Estonia. On "Black Thursday", 23 October 1997 Tallinn Stock Exchange index (TALSE) plunged by 15\%. Two months later TALSE had lost $54 \%$ of its pre-crash level and $62 \%$ of the peak level recorded on 29 August. Although the Estonian economy recovered relatively smoothly and GDP in 1997 increased by 10.5\%, banks did not have time to recover fully from the stock market crash prior to the Russian crisis in 1998 . Contraction in foreign funding, further devaluation of securities portfolios, impairment in credit portfolios, as well as restrictions in regulation led to substantial changes in the banking market.

\footnotetext{
${ }^{8}$ Tang et al. (2000, pp. 34-36) have estimated the fiscal and quasi-fiscal costs of the first and second systemic Estonian banking crisis (1992-93 and 1994-95) to be about 1.9\% of GDP.

${ }^{9}$ The measures to prevent the expansionary developments include (i) an increased capital requirement of $10 \%$ instead of $8 \%$ as of October 1997; (ii) governmental reserves were transferred from domestic banks to foreign banks; (iii) an additional liquidity requirement of $2 \%$ as of November 1997 and 3\% as of December 1997 was introduced; (iv) effective July 1997 the risk category of claims to local governments was increased from $50 \%$ up to $100 \%$; and (v) in December 1997 the general banking reserve requirement of 5\% risk weighted assets became effective.
} 
The crisis again took on a systemic scale in the second half of 1998 when five banks faced severe difficulties. These banks constituted $38 \%$ of all banking sector assets and approximately $40 \%$ of aggregate deposits. All of these banks were either strongly exposed to securities market and/or had a substantial share in projects related to Russia. The aggregate share of nonperforming loans reached the highest level a year after the culmination of Russian crisis, in mid 1999.

By the beginning of 1998 it was clear that a market of less than 1.5 million inhabitants was not large enough to sustain eleven separate banks. The much-needed consolidation and restructuring of the overly fragmented banking sector decreased the number of banks again almost by half. Hitherto widely spread branch networks were cut down and replaced by electronic channels (ATM, internet banking etc). Costefficiency and prudent management turned out to be the key factors in surviving the market distress. Two of the largest banks; Hansapank and Eesti Ühispank, covering more than $80 \%$ of market; were taken over by foreign investors. ${ }^{10}$ Three banks Eesti Maapank, EVEA pank and ERA Pank were forced to close down and two banks - Eesti Hoiupank and Tallinna Pank - were taken over by other domestic banks. One bank - Eesti Forexpank - was temporarily acquired by the central bank. Finally, in April 2005 the sole bank publicly listed on Tallinn stock exchange - Hansapank - was fully overtaken by its strategic investor Swedbank. The financial strength, know-how and expertise of Scandinavian banks concerning risk management, marketing, product development and technology have been essential for the stable development of the Estonian banking sector.

\section{Figure 1: EBRD Index of Banking Sector Reform for Estonia}

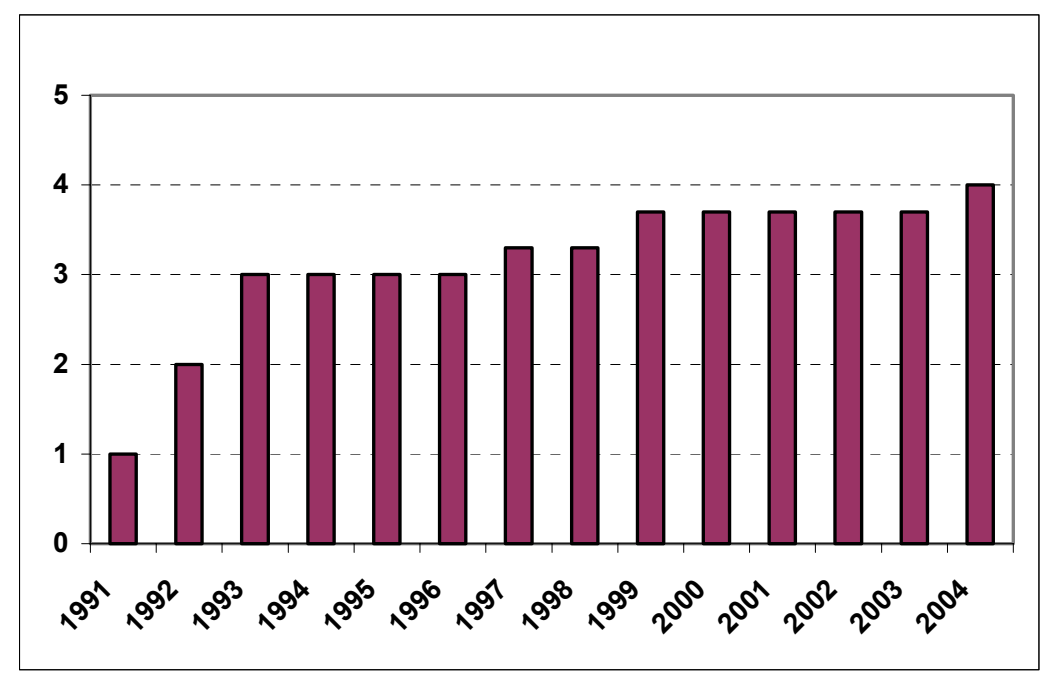

Note: "1" means little progress beyond establishment of a two-tier system; "4+" corresponds to standards and performance norms of advanced industrial countries' provision of full set of banking services. 0.3 decimal points have been added or subtracted for "+" or "“_" ratings.

The gradual improvement in banking sector environment outlined above is also evident from the EBRD banking sector reform index, which demonstrates very low values in the pre-monetary reform period

\footnotetext{
${ }^{10}$ Hansabank was acquired by Swedbank (60\% stake) and Ühispank by SEB (32\% stake).
} 
and the increase in index from 3 at the end of 1996 up to 4 by the end of sample period in 2004. Thus the Estonian banking system has enjoyed a considerable improvement in competence, sophistication, and credibility. ${ }^{11}$ The tightened regulatory environment has eliminated banks unable to survive in the longer term and has helped the Estonian banking sector approach the optimum banking size and structure.

A more detailed insight in to the development of the Estonian banking system over the period 1992 2004 is presented in Table 1. The table reveals the number and distribution of the total number of banks in Estonia as well as the process of consolidation within the banking industry during the run-up to a more open banking-sector environment.

Table 1: Selected Financial Sector Indicators for Estonia (End of Year)

\begin{tabular}{|c|c|c|c|c|c|c|c|c|c|c|c|c|c|}
\hline & 1992 & 1993 & 1994 & 1995 & 1996 & 1997 & 1998 & 1999 & 2000 & 2001 & 2002 & 2003 & 2004 \\
\hline \# of Banks & 42 & 21 & 21 & 15 & 13 & 11 & 6 & 7 & 7 & 7 & 7 & 7 & 9 \\
\hline $\begin{array}{l}\text { \# of Private } \\
\text { Banks }\end{array}$ & 38 & 17 & 21 & 17 & 12 & 11 & 5 & 6 & 7 & 7 & 7 & 7 & 9 \\
\hline $\begin{array}{l}\text { \# of State- } \\
\text { Owned Banks }\end{array}$ & 2 & 2 & 1 & 1 & 1 & 0 & 1 & 1 & 0 & 0 & 0 & 0 & 0 \\
\hline $\begin{array}{l}\text { Concentration } \\
\text { index C2 (\%) }\end{array}$ & $\mathrm{N} / \mathrm{A}$ & 31.20 & 36.05 & 38.71 & 39.92 & 47.03 & 84.80 & 84.00 & 83.00 & 83.33 & 83.96 & 83.29 & 79.10 \\
\hline $\begin{array}{l}\text { Concentration } \\
\text { index C4 (\%) }\end{array}$ & $\mathrm{N} / \mathrm{A}$ & 57.10 & 60.00 & 65.00 & 68.00 & 77.00 & 98.00 & 98.00 & 97.36 & 97.56 & 97.65 & 97.84 & 97.90 \\
\hline $\begin{array}{l}\text { Total Assets, } \\
\text { EEK billion }\end{array}$ & 4.78 & 6.39 & 10.38 & 15.53 & 22.94 & 40.50 & 40.99 & 47.07 & 57.81 & 68.41 & 81.69 & 98.80 & 133.58 \\
\hline $\begin{array}{l}\text { Capital } \\
\text { Adequacy (\%) }\end{array}$ & $\mathrm{N} / \mathrm{A}$ & 18.10 & 13.40 & 14.50 & 12.40 & 13.60 & 17.00 & 16.10 & 13.17 & 14.39 & 15.30 & 14.50 & 13.40 \\
\hline $\begin{array}{l}\text { Foreign } \\
\text { Ownership (\%) }\end{array}$ & $\mathrm{N} / \mathrm{A}$ & $\mathrm{N} / \mathrm{A}$ & 14.73 & 28.96 & 33.41 & 44.20 & 60.72 & 61.60 & 83.60 & 85.44 & 85.93 & 86.12 & 86.03 \\
\hline $\begin{array}{l}\text { Stock market } \\
\text { capitalisation } \\
\text { to GDP in } \%\end{array}$ & $\mathrm{~N} / \mathrm{A}$ & $\mathrm{N} / \mathrm{A}$ & $\mathrm{N} / \mathrm{A}$ & $\mathrm{N} / \mathrm{A}$ & 15 & 20 & 11 & 37 & 34 & 27 & 34 & 42 & 51 \\
\hline $\begin{array}{l}\text { Stock market } \\
\text { turnover to } \\
\text { capitalisation } \\
\text { in } \%\end{array}$ & $\mathrm{~N} / \mathrm{A}$ & N/A & $\mathrm{N} / \mathrm{A}$ & $\mathrm{N} / \mathrm{A}$ & 29 & 167 & 161 & 18 & 19 & 14 & 15 & 18 & 17 \\
\hline
\end{tabular}

Notes: $\mathrm{C} 2$ and $\mathrm{C} 4$ gives the share of total assets of the two and four largest banks, respectively. Capital adequacy on solo basis adheres to the Basel I definition i.e. bank own funds divided by risk weighted assets. EUR $=15.6466$ EEK. Data source: Bank of Estonia Financial Sector Statistics.

In the next section a method that provides timely information about the contemporaneous state of banks is constructed in order to provide the supervisory agencies with a useful tool for analysing current banking conditions.

\footnotetext{
${ }^{11}$ The tight currency board system, with its fixed exchange rate serving as a nominal anchor, helped contain the effects of the banking crises by giving credibility to the conduct of monetary policy.
} 


\section{The Distance-to-Default Measure of Bank Fragility}

The aim of this section is to provide a relatively concise, yet self-contained, overview of the asset value model and the time-varying distance-to-default measure which underpins the bank vulnerability analysis for Estonia. ${ }^{12}$ Bank fragility refers to the uncertainty surrounding a bank's ability to service its debt and obligations.

Exploiting the option nature of equity and making the simplifying assumptions of the Black and Scholes (1973) and Merton (1974) option pricing formula, the time path of the market value of total assets, proxied by a geometrical Brownian motion, follows the stochastic process

$$
\ln V_{T}=\ln V+\left(r-\frac{\sigma^{2}}{2}\right) T+\sigma \sqrt{T} \varepsilon_{T},
$$

which gives the asset value at time $T$ (maturity of debt), given its current value $V$, and its standard deviation $\sigma .^{13}$ The standard normal random component is denoted by serially uncorrelated $\varepsilon_{T} \sim N(0,1)$ and the risk-free interest rate is $r$, if contingency claims are applicable in a risk-neutral world. The default point on the expiry day $(t=T)$ is defined as $\ln V_{T}=\ln B$ where $B$ is the (constant) amount of debt. ${ }^{14}$ The distance from the default point $D$ can then be expressed as:

$$
D=\ln V_{T}-\ln B=\ln V+\left(r-\frac{\sigma^{2}}{2}\right) T+\sigma \sqrt{T} \varepsilon-\ln B
$$

It is useful to normalise the distance-to-default by the firm's volatility, $\sigma$. Some manipulation leads to the normalised distance-to-default

\footnotetext{
${ }^{12}$ Chan-Lau et al. (2004), Crosbie and Bohn (2003) and Gropp et al. $(2002,2004)$ have used the same framework. Crouhy et al. (2000) and Saunders and Allen (2002) offer accessible introductions to asset value and credit risk models. Duffie and Singleton (2003) provide an authoritative introduction to and comparison of asset value models.

${ }^{13}$ The credit risk model considers a firm which is financed through a single debt and a single equity issue. The debt comprises of a bond which matures at time $t=T$. An unobservable process describes the firm's value $V_{t}=E_{t}$ $+B$, where $E_{t}$ and $B$ ascribe the outstanding equity and debt values, respectively. At time $T$, the firm's debt matures. At that time either $V_{T}>B$ will hold, or it will not. In the former case, the remaining value of the firm $E_{T}$ $=V_{T}-B>0$ will belong to the equity holders. In the latter case, the firm defaults on its debt and $E_{T}=0$. Combining the above possibilities, a general expression for the value of the firm's equity at $t=T$ is $E_{T}=\max \left(V_{T}-\right.$ $B, 0)$. Looking at this formula, it is precisely the payoff of a European-type call option on the firm's value $V_{T}$ with strike price $B$. Accordingly, the Black and Scholes (1973) formula for the value of a call option can be applied and investors' implicit views of risk can be extracted from stock prices.

${ }^{14}$ Whereas the relevant measure of the bank's assets is their market value, the book value of debt is the pertinent measure because that is the amount the bank's must repay.
} 


$$
D D=\frac{D}{\sigma \sqrt{T}}-\varepsilon=\frac{\ln \left(\frac{V}{B}\right)+\left(r-\frac{\sigma^{2}}{2}\right) T}{\sigma \sqrt{T}} .
$$

The $D D$ risk score can be viewed as a cardinal ranking relative to default risk, instead of the more conventional ordinal rankings offered by rating agencies. ${ }^{15}$ Since the random component of the bank's asset returns is log-normally distributed, the corresponding expected default probability in terms of the cumulative Normal distribution $N$ is calculated as

$$
\operatorname{prob}=N\left[-\frac{\ln \left(\frac{V}{B}\right)+\left(r-\frac{\sigma^{2}}{2}\right) T}{\sigma \sqrt{T}}\right] \text {. }
$$

The smaller $D D$ is, the higher the default risk is. $D D$ is a metric indicating how many standard deviations the equity holders' call option is in-the-money. The smaller the distance-to-default $D D$, the more likely a default is to occur. To put it differently, the probability of default is precisely the probability of the call option expiring out-of-money. Gropp et al. (2002) have demonstrated that the option-based distance-to-default metric $D D$ is a complete and unbiased indicator which gives an accurate indication of bank distress. $D D$ gives a signal of increased fragility (i) if the bank's asset values decline, (ii) if asset volatility increases, and (iii) if leverage increases. Supervisors may therefore use $D D$ as a screening device to monitor banks. ${ }^{16}$

However, things are not quite as simple as this would suggest. In terms of practical implementation of the model, a shortcoming of the asset value model is that the asset value is not observable. This makes assigning values to it and its volatility problematic. Still, the model provides a useful tool for modelling credit risk and bank vulnerability as it is straightforward to show that analytical solutions for both unobserved variables can be calculated from the firm's equity market value, $E$, and its volatility, $\sigma_{E}$, using the system of equation below:

$$
E=V N\left(d_{1}\right)-B e^{-r T} N\left(d_{2}\right),
$$

\footnotetext{
${ }^{15}$ Reality, as usual, is more complicated. For extended frameworks producing default probabilities for more complex capital structures including equity warrants, convertible bonds, preferred equity, and common equity, see Bensoussan et al. $(1994,1995)$. We do not endeavour to cover this territory as the corresponding data is not available for Estonian banks.

${ }^{16}$ On the contrary, the firm's stock price generally does not satisfy (ii) and (iii) due to the call option implicit in equity.
} 


$$
\sigma_{E}=\left(\frac{V}{E}\right) N\left(d_{1}\right) \sigma
$$

$$
d_{1}=\frac{\ln \left(\frac{V}{B}\right)+\left(r+\frac{\sigma^{2}}{2}\right) T}{\sigma \sqrt{T}},
$$

$$
d_{2}=d_{1}-\sigma \sqrt{T}
$$

Solving backwards yields the asset value $V$, asset volatility $\sigma$, and the option-based $D D$ metric. ${ }^{17}$ With these results in mind, we wish to measure market participants' beliefs concerning bank fragility in Estonia during transition, as distilled from equity prices. ${ }^{18}$ The results are presented in Section 4.

\section{Gauging Option-Based Fragility Scores for Estonian Banks During Transition}

We will now apply, on a monthly basis, the method of analysis proposed in the previous section to Estonian banks during the transition period. We shall first review the main data that are available and that have been used in our work. The main challenge when dealing with transition economies is the availability of long time series.

To obtain results on bank fragility we use available monthly data for the transition period for all Estonian banks except one (Eesti Forexpank, since 21.01.1999 renamed Optiva Pank and since 29.12.2000 Sampo Pank) publicly traded on the local stock exchange, either for the whole sample period or some sub-period. ${ }^{19}$ It should be noted that mergers and acquisitions and bank failings that occurred midway through our sample period caused some banks to drop out of the data set. Balance sheet data are taken from Bank of Estonia financial statistics, banks public reports and Tallinn Stock Exchange news releases. Daily market values of the equity of banks are from Tallinn Stock Exchange. Equity volatility has been approximated by the volatility of daily stock market returns over the preceding month. We make the common assumption that the maturity of the debt equals one year.

We first calculate the distance-to-default fragility scale $D D$ and the corresponding expected default probabilities for each sampled bank and for each time period $t$, using equity market and balance-sheet

\footnotetext{
${ }^{17}$ In equation (5) the option value of equity is computed by "European options". Alternatively, one might also compute the market value of equity by "American options" which can be exercised anytime before $T$. The quantitative results, however, show only minor differences: the $D D$ values are higher in terms of American options but the difference is small. The corresponding results are available upon request.

${ }^{18}$ Alternatively, the banking crisis literature has also suggested to use the share of non-performing loans as a measure of bank distress. Unfortunately, for many countries (including Estonia), such data are available only at low frequencies.

${ }^{19}$ The choice of the sample period is based on data availability. The $D D$ risk score requires that banks are publicly traded and therefore the value of equity is market determined. Prior to the opening of the Tallinn stock exchange in May 1996, data is not available.
} 
data. Our sample represents all relevant financial institutions. ${ }^{20}$ The time dimension of the dataset is constrained by the unavailability of longer stock price series for Estonian banks. Despite this restriction, several of the banks selected faced insolvency, mergers and failure-like episodes during the sample period. The results for the distance-to-default score $D D$ and the corresponding expected default probabilities are illustrated in Figures 2 to 7 below. A concise overview over historic evolutions is also provided.

Figure 2: The Behaviour of the DD Risk Score and Underlying Components for SEB Eesti Ühispank (Union Bank of Estonia)

(Sample Period August 1996 to August 2000)
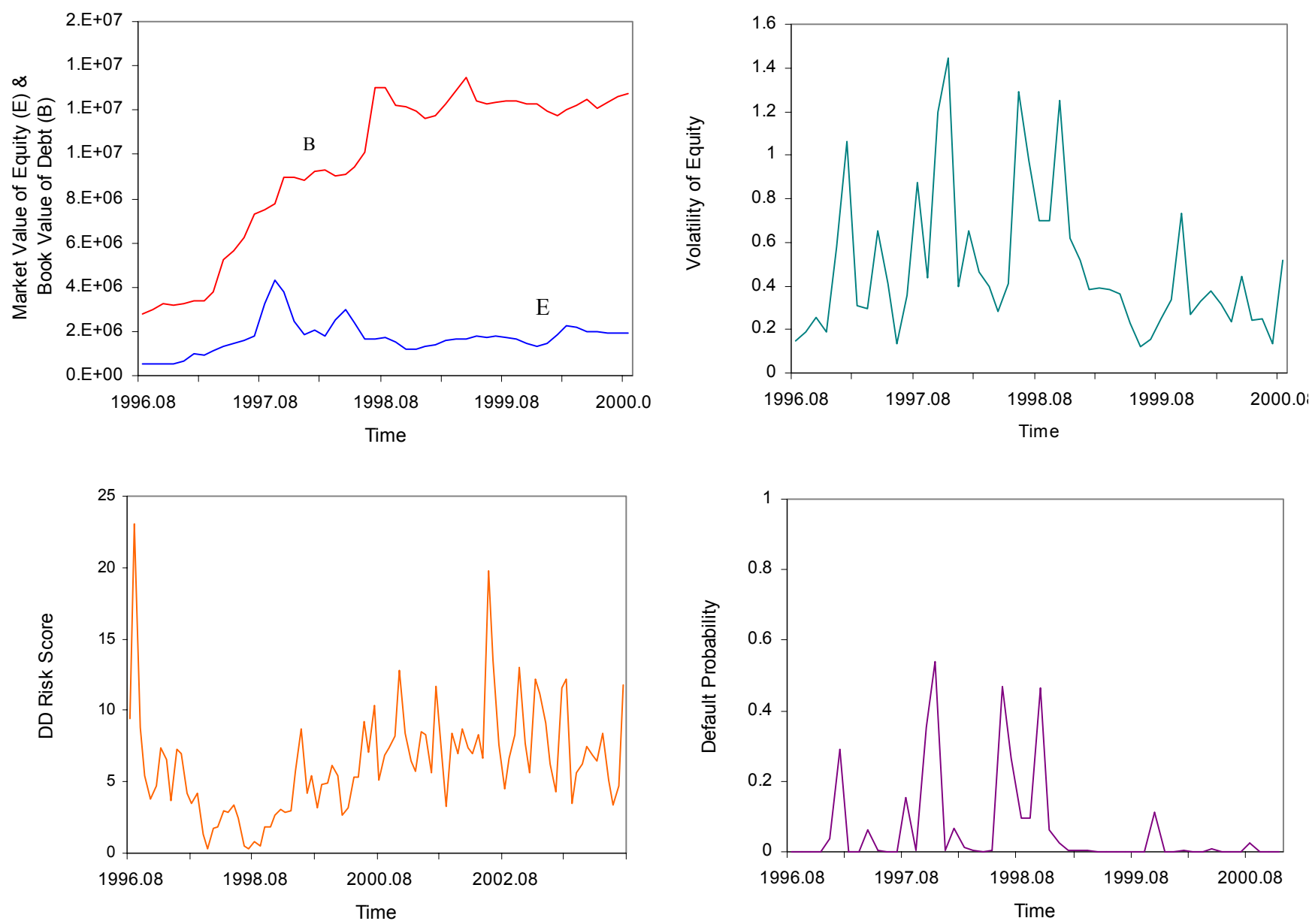

Notes: The data after August 2000 is ignored since $\sigma$ is very small due to the takeover by SEB (Svenska Enskilda Banken).

The images for Eesti Ühispank, in Figure 2, indicate that the $D D$ measures and default probabilities have fluctuated with substantial peaks and troughs. SEB Eesti Ühispank's primary strategic objective

\footnotetext{
${ }^{20}$ Although the banks in our sample are few in number, they account for around $80 \%$ of the banking sector's total assets over the sample period. Further information about the market shares is provided in Appendix A.
} 
over the sample period was to establish a secure position among the largest universal banks in Estonia with ambitions to extend its operations to neighbouring Baltic States and Saint-Petersburg. ${ }^{21}$

The bank's risk measures indicate the period of increasing risk peaking in the aftermath of the stock market crash in October 1997. This period leading up to increased fragility was marked by rocketing share prices and high volatility. Within one year the Ühispank share price had grown eightfold. On 11 September 1997 Ühispank received the investment level rating BBB- from IBCA. This reinforced the euphoria and Ühisbank subsequently issued subordinated debt, not just with the objective of meeting the increased minimum regulatory capital as of 1 October 1997 but mainly for funding expansionary strategies. In September 1997 the bank released the news that it would enter the Russian market by opening a bank in Saint Petersburg. Shortly after this decision the spillover effects from the Asian crisis reversed the stock market and volatilities increased. Uncertainty spread rapidly and market participants became more cautious regarding the downside risk of the stock market and risk of financial instability escalated.

In November 1997 Eesti Ühispank issued a profit warning. In addition, the distress of Eesti Maapank was shaking the Estonian banking sector stability, culminating in the closure of the bank in June 1998. Consolidation became critical in order to survive. Eventually, on 22 April 1998, after long and stressful negotiations Ühispank and Tallinna Pank completed a merger. Ühispank declared losses from October 1998, which summed up to a total loss above 290 million EEK as of the end 1998, leading to a further deterioration of confidence. In this situation the SEB proposal to acquire 32\% of Ühispank share was received with great relief. This move restored confidence in the bank. Moody's confirmed the Ühispank pre-crisis ratings, but indicated a positive outlook for the bank. Standard \& Poor issued the bank with a rating of $\mathrm{BB}$ which put the Estonian banking sector risks on an equal level with Hungary, Poland and Slovenia, but higher relative to other Baltic states due to the vulnerability of the economy from external risks. On 12 October 1999 SEB increased the strategic ownership to 50.15\%. The consecutive takeover on 27 October 2000 finally increased the SEB ownership to $95 \%$. By the end of 2000 SEB full ownership resulted in the termination of trade in Ühispank shares on the Tallinn Stock Exchange.

The results for Hoiupank are provided in Figure 3. Hoiupank was the successor of the Soviet regime savings bank, inheriting a broad depositors base of domestic households. After the merger with Tööstuspank in September 1996 its share of corporate customers rose significantly and Hoiupank achieved the position of second largest market player until Ühispank and Põhja-Eesti Pank merged in May 1997. At the same time, Hoiupank successfully issued debt (400 million EEK) on the international capital markets and received a 160 million EEK subordinated loan from Credit Suisse First Boston. On 26 September 1997 Moodys issued the bank with the long-term credit rating Baa2 and the financial strength rating $D^{+}$. The prospects for attracting further foreign funding were better than ever. On 30 September 1997 Hoiupank acquired FABA bank in Moscow and declared its intention to invest 30

\footnotetext{
${ }^{21}$ Ühispank was Estonia's third largest bank after Hansapank and Hoiupank until May 1997 when it surpassed Hoiupank and has since retained position of second largest bank.
} 
million EEK over the next 18 months. In this environment the Bank of Estonia announced its intention to sell its share in Hoiupank to the present strategic investor Swedbank, whose holding was already $12.5 \%$. The transfer of whole Eesti Pank stake to Swedbank would have increased the Swedbank holding up to $25 \%$. In view of this announcement, the Hoiupank management indicated their reluctance to cooperate with Swedbank and "share the cake". The bank management launched the initiative to issue 3 million shares to Hoiupank staff. Flourishing stock market and good access to external liquidity offered a favourable platform for the realisation of the plan. In order to finance the purchase of shares the Hoiupank staff members limited company applied for a 6 months credit from Japanese Daiwa bank. The loan was collateralised with Hoiupank shares, but Hoiupank management also agreed to offer a Hoiupank guarantee to the credit. This decision turned out to be a fatal mistake.

Figure 3: The Behaviour of the DD Risk Score and Underlying Components for Hoiupank (Sample Period August 1996 to June 1998)
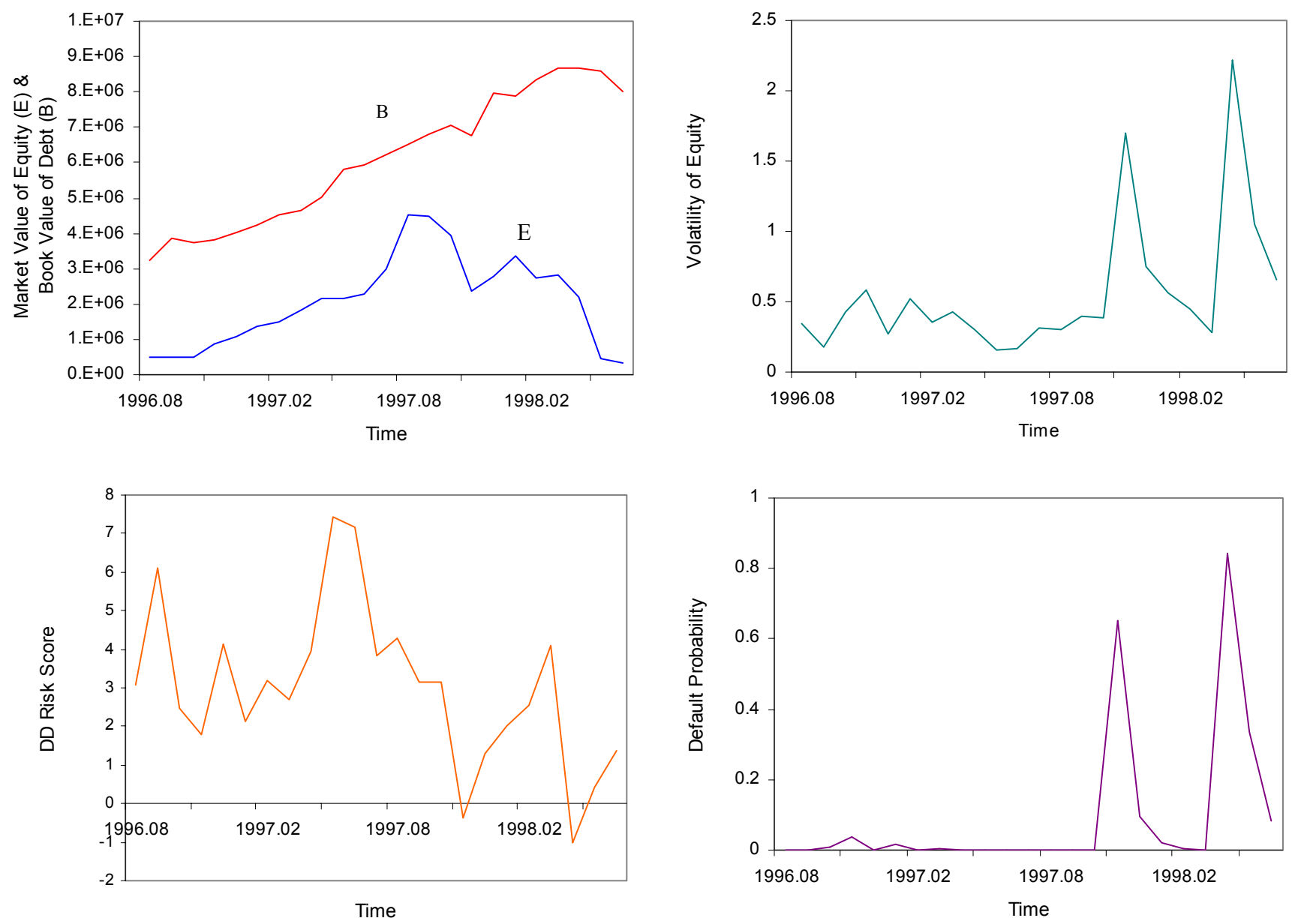

At the beginning of October 1997 Bank of Estonia declared its intention to sell the rest of Hoiupank shares to Swedbank. Hoiupank staff had to hasten the issue project, but it was already too late. The stock market crash at the end of October and the consecutive Russian crisis drove Hoiupank shares below the minimum value necessary to cover the collateral of the Daiwa loan due in April 1998 and the 
need for consolidation became acute. ${ }^{22}$ In January 1998, Hoiupank and Hansapank had already released a letter of intention for merger. The merger was to serve mutual interests - Hansapank was in need to increase the share capital and Hoiupank foresaw the troubles arising from the Daiwa affair. The merger contract was finally signed in June 1998 and Bank of Estonia approved the merger in July. ${ }^{23}$ Trade in Hoiupank shares was terminated at 15 July 1998.

The dating of the $D D$ scores and default probabilities in Figure 3 seems reasonable and reflects the impacts of the stock market crash in October 1997 and the Daiwa affair in spring 1998. DD started to decline already in June 1997 picking up the steadily increasing volatilities at the outset of stock market crash. As expected, the $D D$ (default probability) decrease (increase) in the wake of the Daiwa affair was rather pronounced with a two month lead. The results therefore indicate that the option-based measures are indeed able to anticipate future rating changes.

The results for Evea Pank are illustrated in Figure 4. Evea Pank was the smallest bank publicly listed on the stock market, enduring poor liquidity and high volatility. The market value of EVEA Pank remained moderate even at the peak in Tallinn Stock Exchange. On average the bank covered 2\% of the market share over the sample period. EVEA Pank initially advocated the provision of a broad service range.

This strategy, however, turned out to be costly for a small bank, hindering operational efficiency. For attracting customers the bank offered favourable deposit rates and "tailor-made" services for corporate customers, mainly small and medium size enterprises whose access to credit in larger banks was more complicated. In 1997 along the upturn in stock market the bank saw opportunities for improvement in profitability. As of 23 April 1997 the bank council continued to see healthy profit growth for 1997 from 13 million EEK up to 15 million EEK. This profit increase had to be achieved with enforced activity on capital and money markets. In 1997 the bank purchased Russian government bonds for 146.8 million EEK. This fatal investment accounted for almost $20 \%$ of the bank's assets. Bank reports remained optimistic until the third quarter of 1997. On 5 November 1997, however, the management announced a decrease in profitability due to the declining market value of the trading portfolio. The shortage of liquidity in the aftermath of stock market crash in October 1997 forced the bank to increase deposit rates substantially. Unlike the market leaders, EVEA Pank did not have access to international capital markets or syndicated credit-lines. Therefore, news of ERA Pank's desire to acquire 33\% of EVEA bank shares in December 1997 was welcomed. At 18 August 1998 ERA Pank acquired about 33\% of EVEA Pank shares and replaced one board member. After the devaluation of the Russian rouble in August 1998, Evea Pank's balance sheet weakened substantially and it emerged that the bank was unable to fully satisfy the legitimate claims of its customers. However, weaknesses in risk management

\footnotetext{
${ }^{22}$ At 20 May 1998 Hoiupank declared potential losses from the Daiwa loan reaching up to 225 million EEK.

${ }^{23}$ The case of Hoiupank shows that cronyism does not necessarily stop at Estonia's border. In 1997 several senior managers took out a $\$ 1.5$ million foreign loan, using the bank's equity as collateral, in order to buy - for themselves - part of the bank's new equity offerings. The scheme was derailed by the stock market crash. The managers were fired as the bank merged with a competitor.
} 
and loan assessment systems and poor corporate governance were also important contributors to these problems. At that point, EVEA Pank was effectively insolvent. Therefore, the bankruptcy procedure against EVEA Pank was launched at 2 October $1998 .^{24}$

Figure 4: The Behaviour of the DD Risk Score and Underlying Components for Evea Pank (Sample Period February 1997 to August 1998)
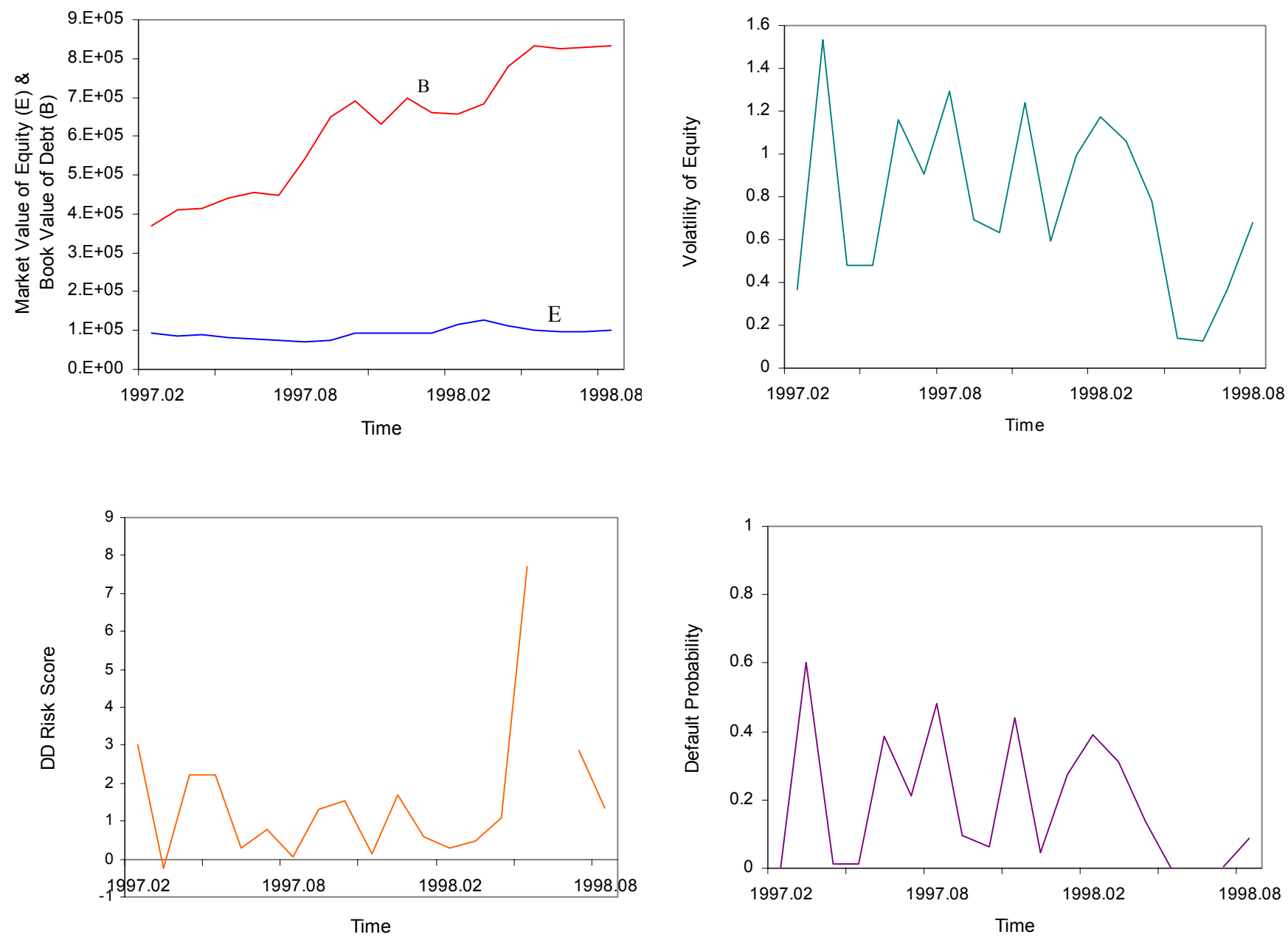

Note: The $\sigma$ variable for June 1998 is so small that the numerical program terminated the $D D$ calculation.

There is no denying that although insolvency was foreseeable, the $D D$ risk score and the corresponding default probabilities failed to indicate the likelihood of EVEA Pank to fall into crisis in summer 1998. A fairly concentrated shareholding structure and noisy measurement of share process in thin markets led to this result. Thus, the results provide evidence against the notion that market price data are uniformly reliable.

The results for Eesti Maapank are available in Figure 5. Eesti Maapank was instituted in 1995 by way of a merger of four smaller local banks, which were unable to meet the minimum capital adequacy

${ }^{24}$ The bankruptcy proceeding was initiated because equity capital of EVEA Pank was less than ECU 5 million. In 
requirement at the end of 1995 or further down the road. The mergers took place as follows: 20 November 1995 the merger of Virumaa Kommertspank and Rahvapank; 11 December 1995 merger of Virumaa Kommertspank and Keila Pank and 2 January 1996 merger between Virumaa Kommertspank and Maapank. On 10 May 1996 the shareholders of the merged institution decided to name the bank Eesti Maapank. The audited financial statements of the merged institution as of 1995 indicated losses of 27.3 million EEK. Although the institution fell short of the prudential ratios, the Bank of Estonia was eager to offer the new entity more time to establish a well-functioning bank. The expected synergies, however, never emerged and the new institution was undermined by opportunism and internal conflicts. In May 1997, after long negotiations EBRD agreed to acquire 19\% of bank shares. At the same time Swedfund granted Maapank a 7 year maturity subordinated loan of 24 million EEK. These developments were of significant help for the undercapitalised bank. Further optimism emerged along with the stock market boom.

Figure 5: The Behaviour of the DD Risk Score and Underlying Components for Eesti Maapank (Sample Period March 1997 to June 1998)
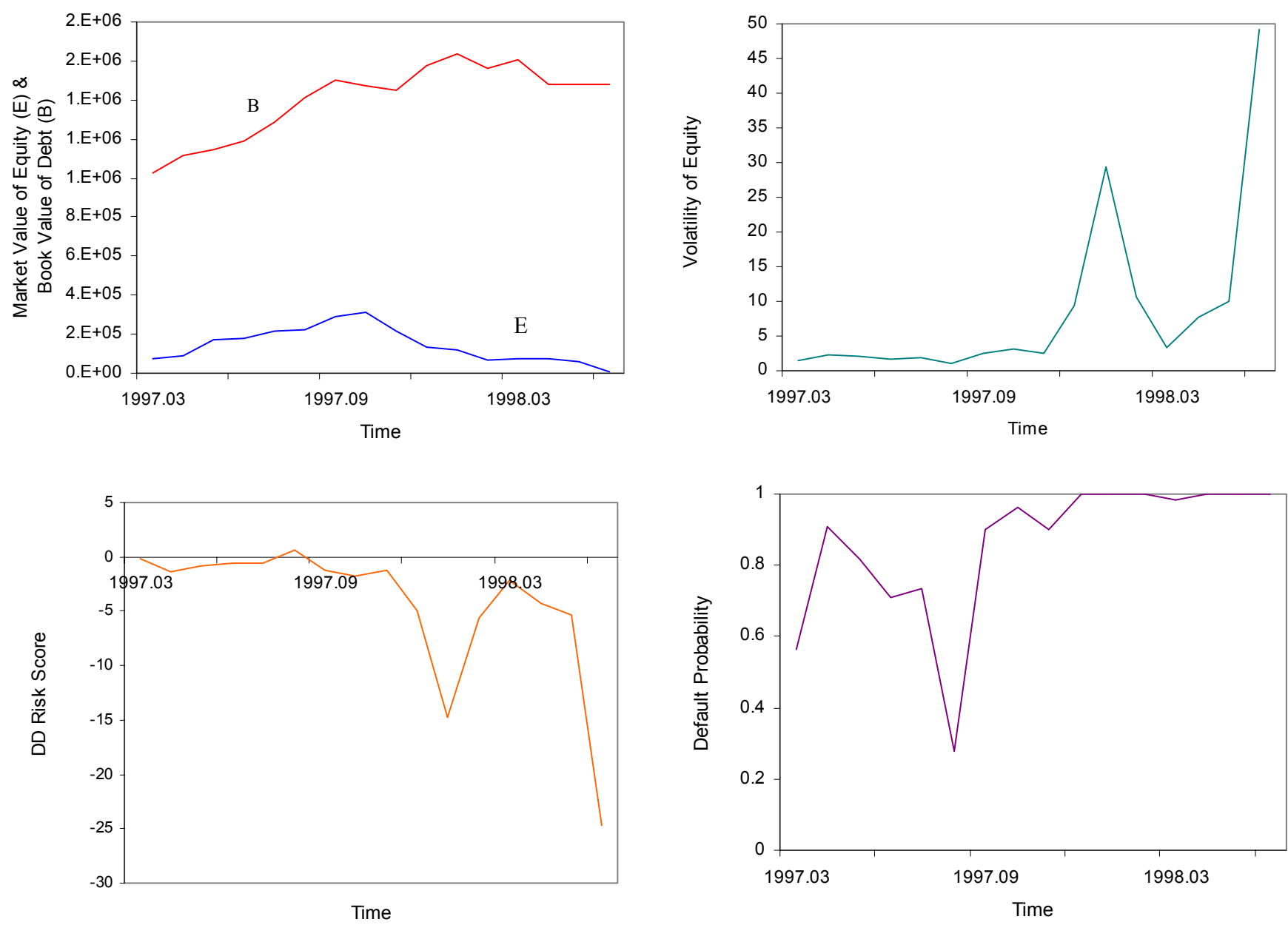

addition, EVEA Pank did neither meet the capital adequacy ratio nor the established reserve requirement. 
Losses stemming from weaknesses in risk management and loan assessment systems and poor corporate governance could be offset, the bank believed, by speculative trading on bull markets. While the bank's trading portfolio was of negligible value at the beginning of 1996, the value at the end of 1997 was already 500 million EEK outnumbering the bank own funds more than seven times. In September 1997 Maapank even announced its intention to list its shares on Tallinn Stock Exchange, but the subsequent developments scuppered this plan.

Maapank initially managed to hide its true losses in the aftermath of Asian crisis, but at the beginning of 1998 insiders were already aware that the bank was technically insolvent and its operations were dependent on overnight money market liquidity. Short-term borrowing was the only way the bank could meet its liabilities and reserve requirements. On 9 March 1998 an audit of Coopers \& Lybrand discovered hidden losses of 192 million EEK not accounted for in bank financial statements. From April of that year Maapank encountered difficulties in securing funding from the money market and therefore the bank failed to meet reserve requirements. On 8 June 1998 Bank of Estonia terminated Eesti Maapank's banking licence and bankruptcy procedures were opened on 16 June 1998. All in all, the bank was kept going for six months by implicit government support before half-hearted regulators finally decided to force Maapank into bankruptcy. The low $D D$ scores and high default probabilities illustrated in Figure 5 accurately capture the high-risk bank and anticipate that the tightening of prudential requirements would prove fatal for Maapank. ${ }^{25}$

The behaviour of the $D D$ risk score and underlying components for Hansapank are depicted in Figure 6. Hansapank is Estonia's biggest financial institution. Hansapank has been Estonia's most successful bank throughout the transition period. Hansapank assumed the position as market leader by the end of 1994 and has successfully defended this position ever since. In December 1995 Hansapank became the first Estonian bank to be listed on the Helsinki stock exchange. It was also, in October 1994, the first bank to receive a loan without government guarantee from the EBRD.

Hansapank was the first bank to acknowledge the constraints of the domestic market. As early as Spring 1996 Hansapank acquired a bank in Latvia and by the end of 2001 Hansapank was represented in all of the Baltic states.

After the stock market peak Hansapank experienced liquidity shortages, coinciding with the first signs of the imminent Asian crisis in September 1997. On 1 September 1997 the executive board of the bank made a proposal to enlarge the Hansapank capital base in order to fund expansionary strategies in Baltic region. On 13 October 1997 an extraordinary shareholder meeting decided to enlarge the bank capital according to the following schedule: 5.5 million shares before 28 February 1998; 1 million shares before 11 October 1998 and 1 million shares toward Hansapank employees before 11 October 2000. The subsequent stock market plummet just ten days later rendered this plan unattractive. In order to overcome the funding constraints and address the medium term strategic objectives Hansapank

\footnotetext{
${ }^{25}$ Their shares were not listed, but traded on the OTC market. Therefore the market was rather thin and highly volatile.
} 
proposed a merger with Hoiupank in January 1998. The merger, however, was only finalised half a year later, in June 1998, after Hoiupank eventually realized its financial impairment in the aftermath of Asian and Russian crises. Moody's reacted to the merger by downgrading Hansapank long term rating from Baa2 to Baa3.

Figure 6: The Behaviour of the $D D$ Risk Score and Underlying Components for Hansapank (Sample Period August 1996 to July 2004)
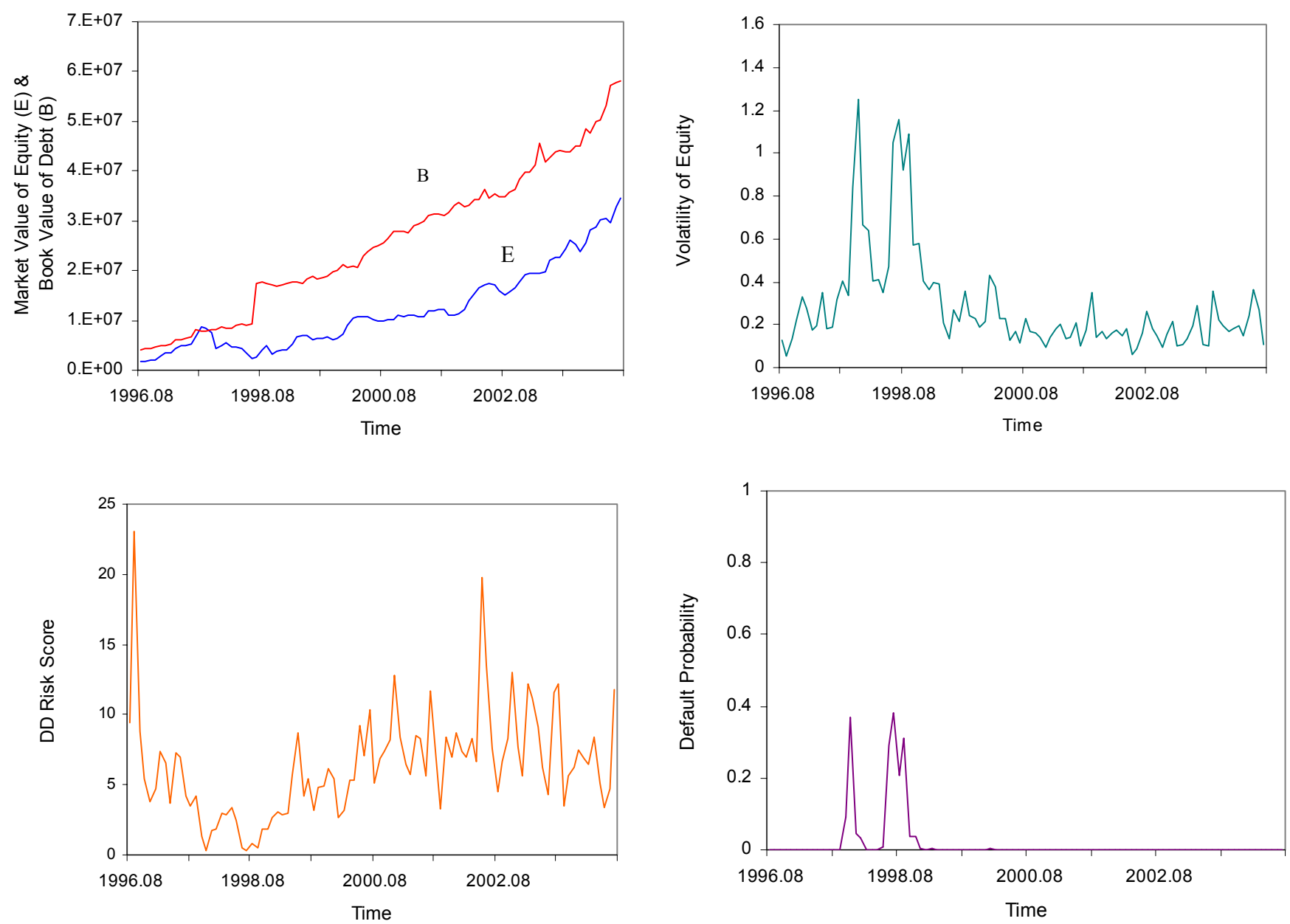

Further tensions grew in tandem with the Russian crisis. The closure of Maapank cultivated serious mistrust towards banking sector. After the devaluation of the Russian rouble in August 1998, Hansapank obtained a DM 10 million subordinated loan in September 1998. In the wake of Russian crisis the Swedish banks SEB and Swedbank discerned the opportunity to acquire Estonian banks. On 29 September 1998 Swedbank and SEB publicly confirmed the SEB sale of all Hansapank shares to Swedbank. As a result the Swedbank share in Hansapank rose to 48.7\%. Although Swedbank claimed its long-term objective was to hold only $25-35 \%$ of Hansapank shares, it increased its ownership further and finally in April 2005 Swedbank bought up the minority shares and achieved full ownership. 
In view of EU accession the struggle for improved efficiency became even more important. The small market limitation had to be compensated with improving cost-efficiency and regional expansion. In 2003 Hansapank entered the Russian market with a leasing subsidiary. In March 2005 Hansapank acquired the Kvest bank in Moskow. In November 2005 Moodys upgraded the bank's financial strength rating up to $\mathrm{C}+$ and gave a positive outlook on the bank's prospects.

How does $D D$ react to these developments and, through $D D$, what types of changes in bank fragility can be captured? $D D$ measures in Figure 6 clearly demonstrate the turmoil in stock market in Autumn 1997 and the subsequent distress related to the Russian crisis in the second half of 1998. The DD fragility indicator declined 3-4 months prior to the outbreak of stock market crash, and preceded the first manifestations of the Russian crisis; the Hoiupank Daiwa loan affair; one month ahead and the Maapank failure two months ahead. In this sense, $D D$ for Hansapank can again be considered to be a forward-looking indicator.

Figure 7: The Behaviour of the DD Risk Score and Underlying Components for Tallinna Pank (Sample Period August 1996 to June 1998)
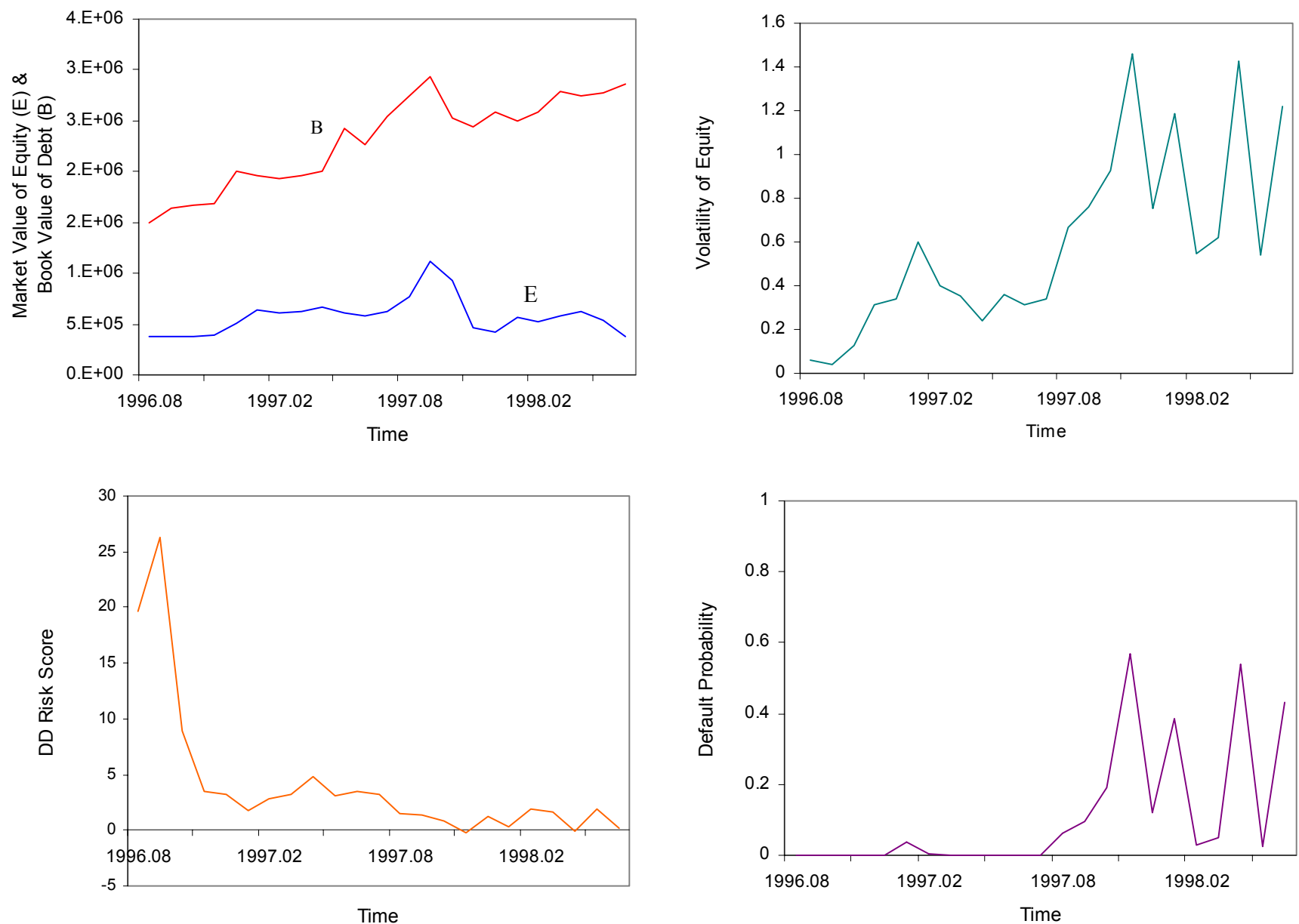

Finally, the calibration results for Tallinna Pank are summarised in Figure 7. Tallinna Pank's strength was good corporate governance. In mid-1996 the bank succeeded in issuing subordinated debt to 
Swedfund and to a Nederland Development bank FMO, besides it received a 12 million DM credit line from EBRD. These and subsequent foreign capital injections enabled Tallinna Pank to enter the neighbouring markets in Latvia and Lithuania. By the end of 1996 Tallinna Pank acquired 20\% of Latvian Saules Banka and instituted a leasing subsidiary in Riga. A year later a leasing business was also founded in Lithuania.

During the financial turmoil of autumn 1997 markets for liquidity were squeezed. In December 1997 the bank cut its profit outlook of 1997 by $22.7 \%$ but nonetheless the outlook was brighter. In that same month the bank received a 10 year maturity subordinated loan from the EBRD, which helped to strengthen the bank's capital base. The bank decided to remain an independent bank and refused to accept the Ühispank merger proposal.

The situation, however, worsened at the onset of the Russian crisis in Spring 1998 and the need for consolidation became acute in order to survive in the hostile banking environment. Tallinna Pank was seen as the desired partner. In March 1998 Tallinna Pank received three proposals for mergers - from Investeermispank, Ühispank, and Hansapank. As Investeerimispank was considered too small and Hansapank was already in negotiations with Hoiupank, the most reliable option turned out to be Ühispank. On 22 April 1998 the merger between Tallinna Pank and Ühispank was finalised. ${ }^{26}$

The $D D$ measures pick up the increasing default risk since July 1997, i.e. three months ahead of the stock market crisis. Contrary to its larger competitors, however, Tallinna Pank's $D D$ score did not improve during the first six months of 1998, i.e. during the short tranquillity period between the stock market crash and outbreak of the Russian crisis. The default probabilities remained at a significantly higher level compared to the pre-crash period until the takeover acquisition in mid 1998.

Prima facie, the results of the Estonian case study appear to indicate that the banking crises were triggered by idiosyncratic and common shocks. Market revaluations occurred rapidly, and exhibit crossbank patterns consistent with reasonable inferences. Furthermore, the risk score differences across banks also indicate that news about one bank did not cause investors to make inappropriate inferences about the conditions of other banks. ${ }^{27}$ The next section evaluates the timeliness of market valuations in comparison to credit rating risk scores for Hansapank, Hoiupank and Ühispank. We are forced to conduct this exercise on this subset of banks for which we have rating information.

\section{The Timeliness of the $D D$ Risk Score Changes versus Credit Rating Migrations}

There is indeed considerable debate about the merits of option-based fragility indicators. This section therefore intends to provide an analysis of the informational content and timing of alternative fragility indicators. In addition to the $D D$ risk score, we look at the information content of credit ratings $(R)$

\footnotetext{
${ }^{26}$ At 22 July 1998 Tallinn Stock exchange terminated the trade of Tallinna Pank shares.

${ }^{27}$ This result seems to reject the possibility that bank investors routinely engage in "pure contagion" inferences about all banks.
} 
and compare them with the $D D$ measure. ${ }^{28}$ Our aim is to detect whether there exists a significant link between the market assessment, as measured by $D D$, and the rating agencies' decisions to revise a given rating. ${ }^{29}$ Does rating agencies' access to unique private information permit earlier identification of changes in bank condition? Since the assessments differ, it would be surprising if they collected exactly the same information at exactly the same times.

We have converted the monthly history of credit ratings of each sampled bank base on Moody's and Standard \& Poor's ratings and converted every alphabetic rating into a numerical value in order to make it comparable with the distance-to-default measure. We opt for a nonlinear conversion in order to reflect the fact that rating changes tend to be associated with increasingly larger changes in default probabilities when they take place at the lower end of the rating scale. ${ }^{30}$ More specifically, every grade has been transformed into the value of the historical default frequency as observed by Estrella (2000). The resulting grades are given in Table 2 .

Table 2: Conversion of Alphabetic Ratings into Numerical Values

\begin{tabular}{|c|c|c|c|c|}
\hline Moody's & $\begin{array}{c}\text { Standard } \\
\text { \& Poor's }\end{array}$ & Fitch & $\begin{array}{c}\text { Average One Year } \\
\text { Default Rates }\end{array}$ & $\begin{array}{c}\text { Numerical } \\
\text { Grade }\end{array}$ \\
\hline A1 & A+ & A+ & 0.00015 & 1 \\
\hline A2 & A & A & 0.0002 & 1.3 \\
\hline A3 & A- & A- & 0.00035 & 2.3 \\
\hline Baa1 & BBB+ & BBB+ & 0.0012 & 8.0 \\
\hline Baa2 & BBB & BBB & 0.00135 & 9.0 \\
\hline Baa3 & BBB- & BBB- & 0.00305 & 20.3 \\
\hline
\end{tabular}

In order to assess the usefulness of $D D$ in a systematic, operational manner, we use Granger causality tests. The Granger causality approach to the question of whether a variable $x$ causes a variable $y$ is to see how much of the current $x$ can be explained by lagged values of $x$ and then to test whether lagged values of $y$ improve the fit. The variable $x$ is said to be Granger-caused by $y$ if the lagged variables of $y$

\footnotetext{
${ }^{28}$ A chronology of rating migrations for Hansapank and Ühispank is provided in the Appendix $B$. Hoiupank has only experienced two rating readjustments: to Baa2 at 26 September 1997 and to Baa3 at 29 May 1998. The presence of government guarantees complicates the process of interpreting market assessments. If de facto or conjectural government guarantees blunt investors' risk exposure, clear evidence of $D D$ risk score changes may be difficult to find because they believe that the government will insulate them from losses. In Appendix $B$ we therefore also provide support ratings where available.

${ }^{29}$ A number of studies have addressed the issue of whether equity data can usefully supplement numerical ratings in the US. Krainer and Lopez (2001) find that stock market information can help forecast downgrades in the supervisory ratings assigned to commercial banks. Gunther et al. (2001) find that stock prices provide useful predictive information even when taking into account past supervisory ratings. Bongini et al. (2002) have analysed the performance of alternative indicators of bank fragility in the East Asian countries during the years 1996-1998. Please note that numerical supervisory ratings from the Bank of Estonia are not available over the entire sample period and therefore cannot be used as a benchmark for banks' soundness.

${ }^{30}$ In particular, the equity market is likely to be more sensitive to information about troubled, low-rated banks with high potential for failure.
} 
are statistically significant. If not, then $y$ does not Granger-cause $x$. Note that feedback is possible; $x$ Granger-causes $y$ and $y$ Granger-causes $x .^{31}$

There are many ways in which to implement a test of Granger causality. One particularly simple approach uses the autoregressive specification of a bivariate vector autoregression for $x$ and $y$. Technically a $F$-test can then be conducted to test for Granger causality. The test results for our historical sample are provided in Table 3.

Table 3 provides a very mixed picture. It appears that Granger causality runs one-way from the distance to default measure $(D D)$ to rating changes $(R)$ for Hoiupank. For SEB Eesti Ühispank two-way causation (feedback) is indeed the case at the $10 \%$ level, while no causal effect can be detected for Hansapank. Neither market indicators nor rating scores cause each other; consistent with the hypothesis that both indicators are quite different. The analysis thus reveals that no one screen consistently outperforms the alternative measure in flagging higher-risk banks. Our results therefore indicate that market and ranking assessments complement one another quite well. Ranking agencies may obtain private information that is not available to market analysts. On the other hand, market analysts may be more forward-looking, making market assessments better predictors of future changes in bank condition. ${ }^{32}$ In other words, optimal vulnerability forecast would be based on both information sets.

Table 3: Pairwise Granger Causality Tests

\begin{tabular}{|l|l|l|l|l|}
\hline Bank & Obs. & Lags & Null Hypothesis & $F$-Statistic \\
\hline Hansapank & 93 & 3 & $D D$ does not Granger cause $R$ & $\begin{array}{l}0.71 \\
(0.54)\end{array}$ \\
\hline & & & $R$ does not Granger cause $D D$ & $\begin{array}{l}0.02 \\
(0.99)\end{array}$ \\
\hline Hoiupank & 19 & 3 & $D D$ does not Granger cause $R$ & $\begin{array}{l}4.60 \\
(0.02)\end{array}$ \\
\hline & & & $R$ does not Granger cause $D D$ & $\begin{array}{l}1.01 \\
(0.42)\end{array}$ \\
\hline SEB Eesti Ühispank & 39 & 9 & $D D$ does not Granger cause $R$ & $\begin{array}{l}2.23 \\
(0.06)\end{array}$ \\
\hline & & & $R$ does not Granger cause $D D$ & $\begin{array}{l}1.98 \\
(0.09)\end{array}$ \\
\hline
\end{tabular}

Notes: (i) The probability values are given below the $F$-statistics in brackets. (ii) Before coming to actual estimation, it is prudent to take a look at the time series characteristics of the data. A model in levels with integrated variables can display serious distortions in the test statistics and the Granger causality tests become even theoretically invalid. Pre-testing using unit root (ADF) tests leads us to difference all I(1) variables. (iii) A caveat of the approach is that Granger-causality tests are sensitive to the choice of lag length. In a first step, we have estimated the appropriate lag lengths via the BIC information criterion. If it turns out that there is remaining autocorrelation, then the lag length is increased and a Hendry-type testing down procedure takes place until no trace of serial autocorrelation can be found. (iv) In order to avoid losing observations at the beginning of sample period due to missing rating assignments before September 1997 the banks have been given risk grade equivalent to historical average default probability of unrated banks about equal to rating Baa3 or BBB-. This approach has been used by FDIC in scoring U.S banks. The arbitrarily given risk grades for observations pre September 1997

\footnotetext{
${ }^{31}$ Although it is natural to test for so-called Granger causality, the term is a misnomer since it has nothing to do with causality in the more common use of the term.

${ }^{32}$ To be valuable, the $D D$ market indicators need not be superior to ratings. They just have to add a new perspective or dimension that helps to provide a more complete picture of a bank's financial soundness.
} 
are also supported by the fact that according to the new Basel framework (option 1) the unrated banks attain risk scores one category less favourable then the sovereign of incorporation. Since September 1997, Estonian Sovereign rating was equal to Baa1, so the unrated banks risk score roughly equal to Baa3 is in principle consistent with this concept.

We close this section with a word of caution. While the evidence seems relatively strong, we should not forget that our sample is fairly small and the sample period extends only over a few years. ${ }^{33}$ Keeping in mind this limitation, looking ahead the results in this paper underline the importance of using a plurality of risk scores when assessing bank vulnerability.

\section{Conclusions}

The Baltic countries have grown rapidly in the past ten years and have started to regain the ground lost under communism. Estonia is growing at about $8 \%$ a year. At that rate, its standard of living will double in about a decade. Over this transition period, Estonia's banking system has undergone a significant transformation from a mono-banking system to a two-tiered system comprising of a central bank and commercial banks.

Against this background we explore for individual Estonian banks the ability of market indicators to assess risk taking in banks during the transition period. Equity-based risk scores depend upon expected future payoffs to investors and are therefore inherently forward looking. What are the overall lessons that can be derived from the evidence? All in all, our results indicate that the distance-to-default measure of bank vulnerability is a reliable and encompassing measure of bank fragility. In particular, the results suggest that the high-frequency fragility measures extracted from market data are a promising, relatively low cost, early warning tool for bank fragility and therefore have practical value for supervisors. ${ }^{34}$ On the other hand, the option-based risk scores should be taken with a grain of salt when they are based on thin markets. In less developed markets it is therefore important to rely on a multiplicity of fragility indicators complementing each other and serving as a cross check of other evaluations, both for central banks and for the public at large. Another caveat pertains to our results, which stems from the small number of banks in the sample. Further systematic evidence on this issue would therefore be very useful since progress in this area will sharpen our understanding of financial markets.

\footnotetext{
${ }^{33}$ Some notes of caution are in order concerning the empirical analysis of Estonian data. First, the market data are only available for a small number of banks. Second, there is a rather small trading volume for some banks, reliability of price information is therefore not entirely satisfactory. The fact that the market is still not deep enough implies that the time series of $D D$ may be subject to disturbing factors such as temporary mispricing.

${ }^{34}$ Note that our empirical results and conclusions are based on historical data. We have no guarantee that stock market signals would continue to be useful under a regime that explicitly incorporates stock market signals into supervisory policy. One potential problem with market price based measures of risk is that bilateral causality may emerge. In considering the role of market prices in monetary policy operations, Bernanke and Woodford (1997) have pointed out that bilateral causality may emerge between market prices and market participants' expectations concerning future monetary and supervisory policies.
} 
Appendix A: Market Shares From 1993 Through 2003 As Measured by Total Assets in \%

\begin{tabular}{|l|c|c|c|c|c|c|c|c|c|c|c|c|}
\hline & $\begin{array}{c}31.12 . \\
1993\end{array}$ & $\begin{array}{c}31.12 . \\
1994\end{array}$ & $\begin{array}{c}191.12 . \\
1995\end{array}$ & $\begin{array}{c}31.12 . \\
1996\end{array}$ & $\begin{array}{c}31.12 . \\
1997\end{array}$ & $\begin{array}{c}31.12 \\
1998\end{array}$ & $\begin{array}{c}31.12 . \\
1999\end{array}$ & $\begin{array}{c}31.12 . \\
2000\end{array}$ & $\begin{array}{c}31.12 . \\
2001\end{array}$ & $\begin{array}{c}31.12 . \\
2002\end{array}$ & $\begin{array}{c}31.12 . \\
2003\end{array}$ & $\begin{array}{c}31.12 . \\
2004\end{array}$ \\
\hline $\begin{array}{l}\text { Eesti } \\
\text { Maapank }\end{array}$ & $2.63 \%$ & $3.07 \%$ & $4.57 \%$ & $4.64 \%$ & $4.41 \%$ & N/A & N/A & N/A & N/A & N/A & N/A & N/A \\
\hline $\begin{array}{l}\text { SEB Eesti } \\
\text { Ühispank }\end{array}$ & $13.88 \%$ & $16.77 \%$ & $17.75 \%$ & $16.52 \%$ & $24.47 \%$ & $33.21 \%$ & $29.65 \%$ & $26.73 \%$ & $31.60 \%$ & $29.90 \%$ & $30.80 \%$ & $30.90 \%$ \\
\hline Evea Pank & $1.52 \%$ & $1.99 \%$ & $1.82 \%$ & $1.78 \%$ & $2.02 \%$ & $1.45 \%$ & N/A & N/A & N/A & N/A & N/A & N/A \\
\hline Hansapank & $15.01 \%$ & $20.42 \%$ & $22.72 \%$ & $25.30 \%$ & $24.77 \%$ & $51.95 \%$ & $54.82 \%$ & $56.76 \%$ & $53.10 \%$ & $53.20 \%$ & $50.40 \%$ & $48.20 \%$ \\
\hline Hoiupank & $12.07 \%$ & $14.75 \%$ & $17.44 \%$ & $19.81 \%$ & $23.77 \%$ & N/A & N/A & N/A & N/A & N/A & N/A & N/A \\
\hline $\begin{array}{l}\text { Tallinna } \\
\text { Pank }\end{array}$ & $5.31 \%$ & $6.10 \%$ & $7.15 \%$ & $9.89 \%$ & $7.74 \%$ & N/A & N/A & N/A & N/A & N/A & N/A & N/A \\
\hline
\end{tabular}

\section{Appendix B: Chronology of Rating Changes for Hansapank and SEB Eesti Ühispank}

\begin{tabular}{|c|c|c|c|}
\hline \multirow{2}{*}{\multicolumn{2}{|c|}{$\begin{array}{l}\text { Hansapank } \\
\text { Moody's Long-Term Ratings: }\end{array}$}} & \multicolumn{2}{|l|}{ SEB Eesti Ühispank } \\
\hline & & \multicolumn{2}{|c|}{ Moody's Long-Term Ratings: } \\
\hline 26 September 1997 & Baa2 & 23 July 1997 & Baa3 \\
\hline 23 July 1998 & Baa3 & 14 March 2000 & $\mathrm{Baa} 2$ \\
\hline 24 August 1999 & Baa2 & 14 November 2000 & Baal \\
\hline 14 March 2000 & Baa1 & & \\
\hline 28 January 2002 & A2 & & \\
\hline 12 December 2002 & A1 & & \\
\hline \multicolumn{2}{|c|}{ Moody's Financial Strength Ratings: } & \multicolumn{2}{|c|}{ Moody's Financial Strenght Ratings: } \\
\hline 26 September 1997 & $\mathrm{D}+$ & 24 August 1999 & $\mathrm{D}$ \\
\hline 2 May 2001 & C- & 14 November 2000 & D \& Positive Outlook \\
\hline 29 July 2002 & C \& Positive Outlook & & \\
\hline 2 May 2003 & $\mathrm{~B} / \mathrm{C}$ & & \\
\hline \multicolumn{2}{|l|}{ Standards \& Poors: } & \multicolumn{2}{|l|}{$N / A$} \\
\hline 11 April 2000 & BBB & - & - \\
\hline \multicolumn{2}{|l|}{ Fitch LT: } & \multicolumn{2}{|l|}{ Fitch LT: } \\
\hline 28 February 2002 & A- & 11 September 1997 & BBB- \\
\hline \multirow[t]{2}{*}{29 April 2004} & A & 4 March 2000 & BBB \\
\hline & & 29 September 2000 & BBB + \\
\hline \multicolumn{2}{|l|}{ Fitch Support Rating: } & \multicolumn{2}{|l|}{ Fitch Support Rating: } \\
\hline 28 June 2001 & 3 & Before 4 March 2000 & 4 \\
\hline Before 6 November 2003 & 2 & 4 March 2000 & 3 \\
\hline After 6 November 2003 & 1 & After 22 July 2003 & 1 \\
\hline
\end{tabular}

Notes: Support ratings offer Fitch's judgement of a potential supporter's (either a sovereign state's or an institutional owner's) propensity to support a bank and of its ability to support it. Its ability to support is set by the potential supporter's own Fitch Long-term debt rating, both in foreign currency and, where appropriate, in local currency. Support ratings have a direct link to Long-term debt ratings, but they do not, however, assess the intrinsic credit quality of a bank. Rather they communicate Fitch Ratings' judgement on whether the bank would receive support should this become necessary. " 1 " denotes a bank for which there is an extremely high probability of external support. The potential provider of support is very highly rated in its own right and has a very high propensity to support the bank in question. "5" denotes a bank for which external support, although possible, cannot be relied upon. Data sources: Banks homepages and HEX homepage (previous Tallinn Stock Exchange). 


\section{References:}

Allen, F. and D. Gale (2000) "Financial Contagion“, Journal of Political Economy 108, 1-33.

Bensoussan, A., Crouhy, M., D. Galai (1994) "Stochastic Equity Volatility Related to the Leverage Effect. I. Equity Volatility Behavior", Applied Mathematical Finance 1, 63-85.

Bensoussan, A., Crouhy, M., D. Galai (1995) "Stochastic Equity Volatility Related to the Leverage Effect. II. Valuation of European Equity Options and Warrants", Applied Mathematical Finance 2, 4359.

Bernanke, B.S. and M. Woodford (1997) "Inflation Forecasts and Monetary Policy", Journal of Money, Credit, and Banking 29, 654-684.

Black, F. and M.S. Scholes (1973) "The Pricing of Options and Corporate Liabilities", Journal of Political Economy 81, 637-654.

Bongini, P., Laeven, L. and G. Majnoni (2002) "How Good is the Market in Assessing Bank Fragility? A Horse Race between Different Indicators", Journal of Banking and Finance 26, 1011-1028.

Caprio, G. and D. Klingebiel (2003) "Episodes of Systemic and Borderline Financial Crises", Worldbank, Finance Research, Washington, mimeo.

Chan-Lau, J.A., Jobert, A. and J. Kong (2004) "An Option-Based Approach to Bank Vulnerabilities in Emerging Markets", IMF Working Paper No. WP/04/33, Washington.

Crosbie, P. and J. Bohn (2003) "Modeling Default Risk: Modelling Methodology", KMV Corporation, San Francisco (http://www.moodyskmv.com/research/whitepaper/ModelingDefaultRisk.pdf).

Crouhy, M., Galai, D. and R. Mark (2000) "A Comparative Analysis of Current Credit Risk Models", Journal of Banking \& Finance 24, 59-117.

De Brandt, O. and P. Hartmann (2000) “Systemic Risk: A Survey”, ECB Working Paper No. 35, Frankfurt.

Demirgüç-Kunt, A. and E. Detragiache (1998) "The Determinants of Banking Crises in Developing and Developed Countries", IMF Staff Papers 45, 81-109.

Demirgüç-Kunt, A. and E. Detragiache (2001) "Financial Liberalization and Financial Fragility", in: Caprio, G., Honohan, P. and J.E. Stiglitz (eds.) Financial Liberalization: How Far, How Fast? Cambridge (Cambridge Univ. Press), 96-122.

Demirgüç-Kunt, A. and E. Detragiache (2005) "Cross-Country Empirical Studies of Systemic Bank Distress: A Survey”, National Institute Economic Review, 192, 68-83.

Diamond, D.W. and P.H. Dybvig (1983) "Bank Runs, Deposit Insurance, and Liquidity", Journal of Political Economy 91, 401-419.

Duffie, D. and K.J. Singleton (2003) Credit Risk:Pricing, Measurement, and Management, Princeton (Princeton Series in Finance).

Estrella, A. (2000) "Credit Ratings and Complementary Sources of Credit Quality Information", Basel Committee on Banking Supervision Working Papers No. 3, Basel. 
Freixas, X., Parigi, B. and J.-C. Rochet (2002) "Systemic Risk, Interbank Relations and Liquidity Provision by the Central Bank", Journal of Money, Credit, and Banking 32, 611-640.

Gropp, R., Vesala, J. and G. Vulpes (2002) "Equity and Bond Market Signals as Leading Indicators of Bank Fragility", ECB Working Paper No. 150, Frankfurt.

Gropp, R., Vesala, J. and G. Vulpes (2004) "Market Indicators, Bank Fragility, and Indirect Market Discipline", Federal Reserve Bank of New York Economic Policy Review 10, 53-62.

Gunther, J.W., Levonian, M.E. and R.R. Moore (2001) "Can the Stock Market Tell Bank Supervisors Anything They Don't Already Know", Federal Reserve Bank of Dallas Economic and Financial Review Second Quarter, 2-9.

Kaminsky, G. and C. Reinhart (1999) "The Twin Crisis - The Causes of Banking and Balance-ofPayment Problems", American Economic Review 89, 473-500.

Krainer, J. and Lopez, J.A. (2001) "Incorporating Equity Market Information into Supervisory Monitoring Models", Journal of Money, Credit and Banking 36, 1043-1067.

Merton, R.C. (1974) “On the Pricing of Corporate Debt: The Risk Structure of Interest Rates”, Journal of Finance 29, 449-470.

Saunders, A. and L. Allen (2002) Credit Risk Measurement: New Approaches to Value at Risk and Other Paradigms, New York (Wiley \& Sons Inc).

Tang, H., Zoli, E. and I. Klytchnikova (2000) "Banking Crises in Transition Economies: Fiscal Costs and Related Issues", World Bank Policy Research Working Paper No. 2484, Washington. 


\section{CESifo Working Paper Series}

(for full list see www.cesifo-group.de)

1585 Christos Kotsogiannis and Robert Schwager, On the Incentives to Experiment in Federations, November 2005

1586 Søren Bo Nielsen, Pascalis Raimondos-Møller and Guttorm Schjelderup, Centralized vs. De-centralized Multinationals and Taxes, November 2005

1587 Jan-Egbert Sturm and Barry Williams, What Determines Differences in Foreign Bank Efficiency? Australian Evidence, November 2005

1588 Steven Brakman and Charles van Marrewijk, Transfers, Non-Traded Goods, and Unemployment: An Analysis of the Keynes - Ohlin Debate, November 2005

1589 Kazuo Ogawa, Elmer Sterken and Ichiro Tokutsu, Bank Control and the Number of Bank Relations of Japanese Firms, November 2005

1590 Bruno Parigi and Loriana Pelizzon, Diversification and Ownership Concentration, November 2005

1591 Claude Crampes, Carole Haritchabalet and Bruno Jullien, Advertising, Competition and Entry in Media Industries, November 2005

1592 Johannes Becker and Clemens Fuest, Optimal Tax Policy when Firms are Internationally Mobile, November 2005

1593 Jim Malley, Apostolis Philippopoulos and Ulrich Woitek, Electoral Uncertainty, Fiscal Policy and Macroeconomic Fluctuations, November 2005

1594 Assar Lindbeck, Sustainable Social Spending, November 2005

1595 Hartmut Egger and Udo Kreickemeier, International Fragmentation: Boon or Bane for Domestic Employment?, November 2005

1596 Martin Werding, Survivor Benefits and the Gender Tax Gap in Public Pension Schemes: Observations from Germany, November 2005

1597 Petra Geraats, Transparency of Monetary Policy: Theory and Practice, November 2005

1598 Christian Dustman and Francesca Fabbri, Gender and Ethnicity - Married Immigrants in Britain, November 2005

1599 M. Hashem Pesaran and Martin Weale, Survey Expectations, November 2005

1600 Ansgar Belke, Frank Baumgaertner, Friedrich Schneider and Ralph Setzer, The Different Extent of Privatisation Proceeds in EU Countries: A Preliminary Explanation Using a Public Choice Approach, November 2005 
1601 Jan K. Brueckner, Fiscal Federalism and Economic Growth, November 2005

1602 Steven Brakman, Harry Garretsen and Charles van Marrewijk, Cross-Border Mergers and Acquisitions: On Revealed Comparative Advantage and Merger Waves, November 2005

1603 Erkki Koskela and Rune Stenbacka, Product Market Competition, Profit Sharing and Equilibrium Unemployment, November 2005

1604 Lutz Hendricks, How Important is Discount Rate Heterogeneity for Wealth Inequality?, November 2005

1605 Kathleen M. Day and Stanley L. Winer, Policy-induced Internal Migration: An Empirical Investigation of the Canadian Case, November 2005

1606 Paul De Grauwe and Cláudia Costa Storti, Is Monetary Policy in the Eurozone less Effective than in the US?, November 2005

1607 Per Engström and Bertil Holmlund, Worker Absenteeism in Search Equilibrium, November 2005

1608 Daniele Checchi and Cecilia García-Peñalosa, Labour Market Institutions and the Personal Distribution of Income in the OECD, November 2005

1609 Kai A. Konrad and Wolfgang Leininger, The Generalized Stackelberg Equilibrium of the All-Pay Auction with Complete Information, November 2005

1610 Monika Buetler and Federica Teppa, Should you Take a Lump-Sum or Annuitize? Results from Swiss Pension Funds, November 2005

1611 Alexander W. Cappelen, Astri D. Hole, Erik Ø. Sørensen and Bertil Tungodden, The Pluralism of Fairness Ideals: An Experimental Approach, December 2005

1612 Jack Mintz and Alfons J. Weichenrieder, Taxation and the Financial Structure of German Outbound FDI, December 2005

1613 Rosanne Altshuler and Harry Grubert, The Three Parties in the Race to the Bottom: Host Governments, Home Governments and Multinational Companies, December 2005

1614 Chi-Yung (Eric) Ng and John Whalley, Visas and Work Permits: Possible Global Negotiating Initiatives, December 2005

1615 Jon H. Fiva, New Evidence on Fiscal Decentralization and the Size of Government, December 2005

1616 Andzelika Lorentowicz, Dalia Marin and Alexander Raubold, Is Human Capital Losing from Outsourcing? Evidence for Austria and Poland, December 2005

1617 Aleksander Berentsen, Gabriele Camera and Christopher Waller, Money, Credit and Banking, December 2005 
1618 Egil Matsen, Tommy Sveen and Ragnar Torvik, Savers, Spenders and Fiscal Policy in a Small Open Economy, December 2005

1619 Laszlo Goerke and Markus Pannenberg, Severance Pay and the Shadow of the Law: Evidence for West Germany, December 2005

1620 Michael Hoel, Concerns for Equity and the Optimal Co-Payments for Publicly Provided Health Care, December 2005

1621 Edward Castronova, On the Research Value of Large Games: Natural Experiments in Norrath and Camelot, December 2005

1622 Annette Alstadsæter, Ann-Sofie Kolm and Birthe Larsen, Tax Effects, Search Unemployment, and the Choice of Educational Type, December 2005

1623 Vesa Kanniainen, Seppo Kari and Jouko Ylä-Liedenpohja, Nordic Dual Income Taxation of Entrepreneurs, December 2005

1624 Lars-Erik Borge and Linn Renée Naper, Efficiency Potential and Efficiency Variation in Norwegian Lower Secondary Schools, December 2005

1625 Sam Bucovetsky and Andreas Haufler, Tax Competition when Firms Choose their Organizational Form: Should Tax Loopholes for Multinationals be Closed?, December 2005

1626 Silke Uebelmesser, To go or not to go: Emigration from Germany, December 2005

1627 Geir Haakon Bjertnæs, Income Taxation, Tuition Subsidies, and Choice of Occupation: Implications for Production Efficiency, December 2005

1628 Justina A. V. Fischer, Do Institutions of Direct Democracy Tame the Leviathan? Swiss Evidence on the Structure of Expenditure for Public Education, December 2005

1629 Torberg Falch and Bjarne Strøm, Wage Bargaining and Political Strength in the Public Sector, December 2005

1630 Hartmut Egger, Peter Egger, Josef Falkinger and Volker Grossmann, International Capital Market Integration, Educational Choice and Economic Growth, December 2005

1631 Alexander Haupt, The Evolution of Public Spending on Higher Education in a Democracy, December 2005

1632 Alessandro Cigno, The Political Economy of Intergenerational Cooperation, December 2005

1633 Michiel Evers, Ruud A. de Mooij and Daniel J. van Vuuren, What Explains the Variation in Estimates of Labour Supply Elasticities?, December 2005

1634 Matthias Wrede, Health Values, Preference Inconsistency, and Insurance Demand, December 2005 
1635 Hans Jarle Kind, Marko Koethenbuerger and Guttorm Schjelderup, Do Consumers Buy Less of a Taxed Good?, December 2005

1636 Michael McBride and Stergios Skaperdas, Explaining Conflict in Low-Income Countries: Incomplete Contracting in the Shadow of the Future, December 2005

1637 Alfons J. Weichenrieder and Oliver Busch, Artificial Time Inconsistency as a Remedy for the Race to the Bottom, December 2005

1638 Aleksander Berentsen and Christopher Waller, Optimal Stabilization Policy with Flexible Prices, December 2005

1639 Panu Poutvaara and Mikael Priks, Violent Groups and Police Tactics: Should Tear Gas Make Crime Preventers Cry?, December 2005

1640 Yin-Wong Cheung and Kon S. Lai, A Reappraisal of the Border Effect on Relative Price Volatility, January 2006

1641 Stefan Bach, Giacomo Corneo and Viktor Steiner, Top Incomes and Top Taxes in Germany, January 2006

1642 Johann K. Brunner and Susanne Pech, Optimum Taxation of Life Annuities, January 2006

1643 Naércio Aquino Menezes Filho, Marc-Andreas Muendler and Garey Ramey, The Structure of Worker Compensation in Brazil, with a Comparison to France and the United States, January 2006

1644 Konstantinos Angelopoulos, Apostolis Philippopoulos and Vanghelis Vassilatos, RentSeeking Competition from State Coffers: A Calibrated DSGE Model of the Euro Area, January 2006

1645 Burkhard Heer and Bernd Suessmuth, The Savings-Inflation Puzzle, January 2006

1646 J. Stephen Ferris, Soo-Bin Park and Stanley L. Winer, Political Competition and Convergence to Fundamentals: With Application to the Political Business Cycle and the Size of Government, January 2006

1647 Yu-Fu Chen, Michael Funke and Kadri Männasoo, Extracting Leading Indicators of Bank Fragility from Market Prices - Estonia Focus, January 2006 